\title{
Research on Consumers' Judging Process for Price
}

\author{
YehuA ZHOU \\ Independent Researcher \\ Nakao Home Builder \\ Fukuoka, Japan \\ Hiromi YAMAGATA \\ Faculty of Design \\ Nishinippon Institute of Technology \\ Kitakyushu, Fukuoka, Japan \\ E-mail:yamagata@nishitech.ac.jp
}

\section{About the authors}

Yehua Zhou received her M.A. in Engineering from the graduate school of Nishinippon Institute Technology, Japan. She has been working at Nakao Builders' office since April 2017. Her research focuses on consumer behavior study.

Hiromi Yamagata received her M.A. in Education from Kyoto University, Japan. She is currently working at the Faculty of Design of Nishinippon Institute Technology (Japan) as an associate professor. Her current research interest includes educational psychology and science learning.

\section{Abstract}

The purpose of this paper is to discuss the irrationality of the consumers in their purchasing behavior. The former of this paper verifies the effect of price down on the consumers. As a result, he data shows that price down in Japan functions as a significant factor in promoting sales. The latter part of this paper investigated the relatively effective indication method for pricing down of merchandise. The discounted price indicated by a percentage has more impact on consumers in the case of expensive merchandise, while for relatively cheaper, it is better to mark the amount of the price rather than the discount rate to attract the attention of consumers.

Keywords:Consumer, Price below the benchmark, Judgment of price, Price down, Different cultures 


\section{消費者の価格判断過程に関する研究}

周業華

インディペンデントリサーチャ

株式会社中尾工務店

1021762659@qq.com

山縣宏美

建築学科

西日本工業大学デザイン学部

E-mail:yamagata@nishitech.ac.jp

\section{abstract}

本研究では, 大学生を対象に, 消費者の価格判断の過程, 特に大台割れ価格の効果について, 桁が変わる場合, 先 頭の数字が変わる場合，大台割れではない值下げの場合を比較し，また，その効果について日中比較を行った。そ の結果，值段に対する印象については，日本の場合，大台割れ価格の効果は見られ，元の值段と比べて安いと感じ ることが明らかになった。しかし，中国の場合，大台割れに関係なく，割引したものを安いと感じることが示唆さ れた。購買意志については，日本では，桁が変わる場合のみしか有意差は見られず，大台割れ価格の効果は，桁が 変わる場合により強く見られるということが示唆された。また，中国では，大台割れに関係なく，割引されたもの の方を買いたいと思う傾向が特に 10 元台の場合に見られた。 キーワード:消費者, 大台割れ，価格判断，值引き，異文化 


\section{はじめに}

これまで標準的な経済理論が前提としてきたのは，認知や判断に関して合理的に自己の物質的利益を追求する人間 像であった。しかし近年，人は常に合理的な判断を行うわけではなく，非合理的に思えるような判断を行う場合が あることが指摘され，それは行動経済学という分野として盛んに研究が行われてきている。

人の経済的行動は，資源を利用して財を作る生産行動と，その財を元に欲求を満足させる消費者行動に分ける ことができる。本研究では消費行動のうち, 購買行動に焦点を当て, 消費者の非合理性について検討を行うことを 目的とした。購買行動には，購買計画，商品選択，価格判断などの下位過程が含まれるが，本研究では価格判断に ついての研究を行ったが，今回は特に日本で購買行動を促進する価格設定方略として使用されている「大台割れ価 格」をとりあげることとした。

近年, 観光ビザの発給要件の緩和により, 中国から日本への観光客が増加している。一時期，中国からの観光 客が日本の製品を大量に買う様子が「爆買い」などと称され，日本のメディアでも多く取り上げられていたが，最 近はそのような報道も少なくなってきている。日本で使用されている大台割れ価格は中国でも同様に使用されて いるが，そのような価格設定が日本人，あるいは中国人に対してどのような影響を及ぼすのか詳細に検討すること によって，日本人に対してだけでなく，中国からの観光客に対しても効果的な值段設定を行う際の一助となると考 えられる。

\section{消費者の価格判断の過程}

(a) 心的ものさしと価格判断

価格判断における心理過程の研究では, カーネマンとトゥベルスキー（1979）の「プロスペクト理論」や，小 嶋（1986）の「心理的財布」が重要な貢献を与えた。これらの理論は，価格判断が状況によって異なることを説明 している。その理由を，プロスペクト理論では，意思決定問題のフレーミングが状況によって異なることに起因さ せ，心理的財布の理論では，状況によって異なる心理的財布に起因させている。つまり，両理論とも，価格判断に おいて，状況に応じたある種の心理的編集の過程が存在することを仮定していることになる（竹村, 2000）。

そこで竹村（1998）は心的モノサシの概念を提唱している。心的ものさしの概念は，ものさしの比喻を用いた 心理的評価関数の表現である。いわば消費者が「心的ものさし」で価格を評価すると考える。この概念では，価格 を判断する際に使用されるモノサシの特徵として, 長さが有限であること, 一次元的なものであること, 目盛りが あること，両端が目立ちやすいことを上げている。

(b) 大台割れ価格とは何か

大台割れ価格とは「980 円」といった「1000 円」という大台を意識させない価格表示のことであり，消費者の 心理的抵抗を少なくし，消費者に買いやすい值段であると知覚させると考えられている（小嶋，1986)。このよう な大台割れの効果は, 心的モノサシの端点の敏感さが関連すると考えられ, 消費者の価格判断は非線形性を示すと 考えることができる。

このような大台割れ価格は日常でよく見るものであるにもかかわらず，研究としてはほぼ扱われていない。日 本で唯一みられる研究として, 小嶋（1986）は 10 万円前後のルームクーラー, 5 万円前後のテレビ, 3 万円前後の 
オルガン, 1 万円前後の扇風機, 1000 円前後のお中元詰め合わせセット，100 円前後のハンカチセットの $6 \supset$ つ 商品について，大台割れ価格の効果について調べている。この調査では，被験者となった主婦を 2 群に分け，大台 割れ価格表示の群と大台にのった価格表示の群とで「高いと感じるか, 安いと感じるか」についての 5 段階評定を させ，大台割れ価格の方が安いと感じることを明らかにしている。しかし，大台割れ価格と大台より高い価格を比 較しているため（たとえば，扇風機が 10200 円の場合と 9800 円の場合の比較など)，大台割れ価格の方が安いと感 じるのはあたりまえと言え，大台の価格と大台割れの価格で安さの感じ方が異なるのかは明らかになっていない。

そして，大台割れといっても 1000 円が 980 円になるような，枌自体が変わってしまうものと，2000 円が 1980 円になるように，先頭の数字が変わるのみのものの区別がなされていない。本研究では，このような表記の違いに も大台割れの効果がみられるか検討することとした。

(c) 文化による違い

また，このような大台割れ価格は日本だけでなく，他の国でも使用されている。たとえば中国でも，99 元と いった值段表記はよく使用されている。本研究では，大台割れ価格の効果が日本だけでなく，中国でもみられるか どうかもあわせて検討することとした。

\section{研究}

\section{研究の目的}

本研究では大台割れ価格の効果を実証することを目的とした。また，その効果に影響する要因として，大台割れ によって桁が変わるかどうかと, 值段自体の桁数の影響, また，文化による効果の違いが見られるかどうかを検討 した。

\section{方法}

(a) 研究対象者

西日本工業大学デザイン学部一年生の 62 名の学生（男性は 48 名, 女性は 14 名）と遼寧工業大学の 40 名の学 生（男性は 17 名，女性は 13 名）を対象とした。

(b) 材料と手続き

まず，日本で行った調査では，元の值段が 100 円台のもの，1000 円台のもののそれぞれで，大台割れによって 桁が変わるもの，桁が変わらないが先頭の数字が変わるもの，大台割れではないものの 3 パターンの設定を行った (Fig.⿴囗十参照)。使用された值段と商品はすべて固定であった。大台割れによって枌が変わるものは，100円が 98 円，1000 円が 980 円となるように，大台割れによって，元の值段より值下げした值段が一椼下がるようになって いた。また，椼が変わらないが先頭の数字が変わるものは，200 円が 196 円，2000 円が 1960 円となるように，大 台割れによって，元の值段と值下げした值段の桁は変わらないが，值下げした值段は元の值段の先頭の数字より 1 小さくなるようになっていた。そして比較として，250 円が 245 円，2500 円が 2450 円のように大台割れではな く，単に值下げをする条件のものも作成した。

中国で行った調査では, 日本とほぼ同等の值段設定となるよう，元の值段が 10 元台のもの，100 元台のものの それぞれで, 大台割れによって桁が変わるもの, 桁が変わらないが先頭の数字が変わるもの, 大台割れではないも 


\begin{tabular}{|c|c|c|c|}
\hline & 桁が変わるもの & 先頭の数字が変わるもの & 大台割れではないもの \\
\hline $\begin{array}{l}100 \text { 円 } \\
\text { 台 }\end{array}$ & $\begin{array}{l}\text { お菓子 } \\
\text { / } 100 \text { 円 } \\
-98 \text { 円 }\end{array}$ & $\begin{array}{l}\text { お茶 / } 200 \\
\text { 円-196 円 }\end{array}$ & $\begin{array}{l}\text { サンドイ } \\
\text { ッチ/ } \\
250 \text { 円ー } \\
245 \text { 円 }\end{array}$ \\
\hline $\begin{array}{l}1000 \text { 円 } \\
\text { 台 }\end{array}$ & $\begin{array}{l}\text { 靴下三 } \\
\text { 足/ } 1000 \\
\text { 円 }-980 \\
\text { 円 }\end{array}$ & $\begin{array}{l}\text { ベルト / } \\
2000 \text { 円ー } \\
1960 \text { 円 }\end{array}$ & $\begin{array}{l}\text { サンダ } \\
\text { ル / } \\
2500 \text { 円 } \\
-2450 \\
\text { 円 }\end{array}$ \\
\hline
\end{tabular}

Fig. 1 西日本工業大学学生に向けた価格の例

\begin{tabular}{|c|c|c|c|}
\hline & 桁が変わるもの & 先頭の数字が変わるもの & 大台割れではないもの \\
\hline 10 元台 & 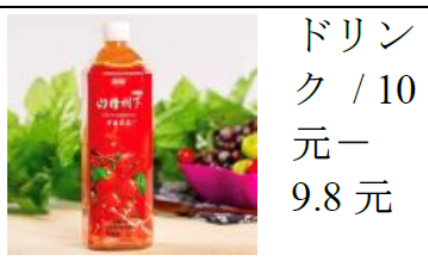 & 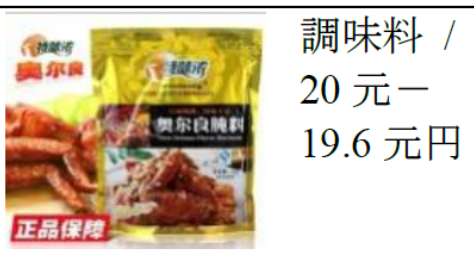 & 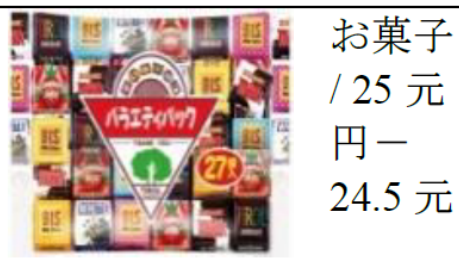 \\
\hline $\begin{array}{l}100 \text { 元 } \\
\text { 台 }\end{array}$ & 服 $\begin{array}{l}\text { 服 } / 100 \\
\text { 元 }-98 \text { 元 }\end{array}$ & 鞄 / 200 元 & $\begin{array}{l}\text { ベルト / } \\
250 \text { 元一 } \\
245 \text { 元 }\end{array}$ \\
\hline
\end{tabular}

Fig. 2 遼寧工業大学学生に向けた価格の例

のの 3 パターンの設定を行った（Fig.四参照）。使用された值段と商品はすべて固定であった。值下げの価格は全 て元の值段の $2 \%$ とした。

材料として使用した商品は，值段が 100 円台，もしくは 10 元台のものは食品のカテゴリーから，值段が 1000 円台，もしくは 100 元台のものは服飾品のカテゴリーから，それぞれの值段で実際に販売されているものの中か ら選んだ。商品のカテゴリーはそろえるべきなのだが，1000 円台，100 元台で購買できる食品は贅沢品となって しまい，また 100 円台，10 元台で購買できる服飾品もあまりないことから，それぞれの值段に応じたカテゴリー として選択した。

質問紙はこれらの品物の写真をページの上部に載せ、これらの值段が○円である場合，值段が高いと思うかど うか（1-非常に安い 2-やや安い 3-普通 4-やや高い 5-非常に高い), 買いたいと思うかどうか（1-買う 2-買っても いい3-どちらでもいい4-あまり買おうと思わない 5-買わない）をそれぞれ 5 段階評定で評定するようになってい た。1ページの中でまず元の值段について評定し，その後值下げした值段について評定させた。提示する品物の順 番はカウンターバランスを行った。

研究対象者は質問紙を配布され, 回答を求められた。日本では集団で実施し, 中国では個別で実施した。 
Table 1 值段についての評定平均值一西日本工業大学の場合（カッコ内は標準偏差）

\begin{tabular}{|c|c|c|c|c|c|}
\hline & & 元の值段 & 值下げした值段 & 差 & $95 \%$ 信頼区間 \\
\hline \multirow{2}{*}{ 桁が変わるもの } & 100 円台 & $2.92(0.91)$ & $2.47(0.97)$ & $0.45(0.71)$ & $0.27-0.63$ \\
\cline { 2 - 6 } & 1000 円台 & $3.31(0.88)$ & $2.90(1.67)$ & $0.40(0.75)$ & $0.21-0.59$ \\
\hline \multirow{2}{*}{ 先頭が変わるもの } & 100 円台 & $3.60(1.09)$ & $3.27(1.20)$ & $0.32(0.78)$ & $0.13-0.52$ \\
\cline { 2 - 6 } & 1000 円台 & $3.61(0.98)$ & $3.44(1.08)$ & $0.18(0.68)$ & $0.00-0.35$ \\
\hline \multirow{2}{*}{ 大台割れでないもの } & 100 円台 & $3.39(0.82)$ & $3.35(0.81)$ & $0.03(0.54)$ & $-0.10-0.17$ \\
\cline { 2 - 6 } & 1000 円台 & $3.84(1.01)$ & $3.81(1.04)$ & $0.03(0.31)$ & $-0.05-0.11$ \\
\hline
\end{tabular}

Table 2 值段についての評定平均值一遼寧工業大学の場合（カッコ内は標準偏差）

\begin{tabular}{|c|c|c|c|c|c|}
\hline & & 元の值段 & 值下げした值段 & 差 & $95 \%$ 信頼区間 \\
\hline \multirow{2}{*}{ 桁が変わるもの } & 10 元台 & $3.27(0.77)$ & $3.16(0.83)$ & $0.11(0.31)$ & $0.00-0.21$ \\
\cline { 1 - 6 } & 100 元台 & $2.72(0.73)$ & $2.57(0.73)$ & $0.16(0.37)$ & $0.04-0.29$ \\
\hline \multirow{2}{*}{ 先頭が変わるもの } & 10 元台 & $3.16(0.73)$ & $3.00(0.75)$ & $0.16(0.37)$ & $0.04-0.29$ \\
\cline { 2 - 7 } & 100 元台 & $3.27(0.69)$ & $3.11(0.66)$ & $0.16(0.37)$ & $0.04-0.29$ \\
\hline \multirow{2}{*}{ 大台割れでないもの } & 10 元台 & $2.51(0.80)$ & $2.32(0.85)$ & $0.19(0.51)$ & $0.02-0.36$ \\
\cline { 2 - 7 } & 100 元台 & $3.35(0.72)$ & $3.16(0.76)$ & $0.19(0.46)$ & $0.04-0.34$ \\
\hline
\end{tabular}

\section{結果}

それぞれの評定値について，值段については非常に安いを 1 点，やや安いを 2 点，普通を 3 点，やや高いを 4 点， 非常に高いを 5 点とし，買いたいかどうかについても，買うを 1 点，買ってもいいを 2 点，どちらでもいいを 3 点，あまり買おうと思わないを 4 点，買わないを 5 点とし，それぞれの平均值と標準偏差を求めた。また元の值段 と值下げした值段の差の平均值と標準偏差を求め, 值段のパターンと值段の桁数の 2 要因分散分析を行った。ま た，その差の平均の 95 \%信頼区間を求めた (Table凹, Table凹, Table四,Table四参照)。

その結果，まず值段については，日本の場合，值段のパターンの主効果がみられ $(F(2,122)=10.11, p<.01)$, ライアン法による多重比較の結果，桁が変わるものと先頭の数字が変わるものには有意差がみられなかったが，ど ちらも大台割れでないものとは有意差がみられ，桁が変わるものと先頭の数字が変わるものの方が元の值段と值引 きした值段の評定の差が大きかった。值段の桁数の主効果 $(F(1,61)=2.374, n . s$.$) と值段のパターンと桁数の交$ 互作用 $(F(2,122)=0.704, n . s$.$) は有意ではなかった。また，95\%信頼区間の結果からも，桁が変わるものと先$ 頭の数字が変わるものでは，元の值段と值引きした值段の評定に有意差がみられたが，大台割れでないものでは有 意差がみられなかった。

一方, 中国の場合, 值段のパターン $(F(2,72)=0.407, n . s$.$) , 桁数の主効果 (F(1,36)=0.130, n . s$.$) , 交互$ 作用 $(F(2,72)=0.145, n . s$.$) すべて有意ではなかった。95\%信頼区間の結果から, 桁が変わるもの, 先頭の数$ 字が変わるもの，大台ではないものそれぞれの 10 元台と 100 元台ともに有意差がみられ，大台割れに関係なく， 安くなっている方の值段を安いと感じるという傾向がみられた。 
Table 3 購買意思についての評定平均值一西日本工業大学の場合（カッコ内は標準偏差）

\begin{tabular}{|c|c|c|c|c|c|}
\hline & & 元の值段 & 值下げした值段 & 差 & $95 \%$ 信頼区間 \\
\hline \multirow{2}{*}{ 桁が変わるもの } & 100 円台 & $3.05(1.18)$ & $2.81(1.33)$ & $0.24(0.50)$ & $0.12-0.37$ \\
\cline { 2 - 6 } & 1000 円台 & $3.15(1.29)$ & $2.74(1.37)$ & $0.40(0.91)$ & $0.17-0.63$ \\
\hline \multirow{2}{*}{ 先頭が変わるもの } & 100 円台 & $3.61(1.23)$ & $3.47(1.29)$ & $0.15(0.76)$ & $-0.05-0.34$ \\
\cline { 2 - 6 } & 1000 円台 & $3.77(1.15)$ & $3.72(1.13)$ & $0.05(0.71)$ & $-0.13-0.23$ \\
\hline 大台割れでないもの & 100 円台 & $3.14(1.19)$ & $3.13(1.17)$ & $0.02(0.38)$ & $-0.08-0.11$ \\
\cline { 2 - 6 } & 1000 円台 & $4.00(1.15)$ & $4.03(1.07)$ & $-0.03(0.36)$ & $-0.12-0.06$ \\
\hline
\end{tabular}

Table 4 購買意思についての評定平均值一遼寧工業大学の場合（カッコ内は標準偏差）

\begin{tabular}{|c|c|c|c|c|c|}
\hline & & 元の值段 & 值下げした值段 & 差 & $95 \%$ 信頼区間 \\
\hline \multirow{2}{*}{ 桁が変わるもの } & 10 元台 & $3.16(1.12)$ & $2.91(1.30)$ & $0.24(0.67)$ & $0.02-0.47$ \\
\cline { 2 - 6 } & 100 元台 & $2.81(1.00)$ & $2.60(0.98)$ & $0.22(0.53)$ & $0.04-0.39$ \\
\hline \multirow{2}{*}{ 先頭が変わるもの } & 10 元台 & $3.13(1.08)$ & $2.92(1.21)$ & $0.22(0.53)$ & $0.04-0.39$ \\
\cline { 2 - 6 } & 100 元台 & $3.16(1.12)$ & $2.97(1.24)$ & $0.19(0.65)$ & $-0.03-0.41$ \\
\hline 大台割れでないもの & 10 元台 & $2.60(0.98)$ & $2.32(1.03)$ & $0.27(0.68)$ & $0.04-0.50$ \\
\cline { 2 - 6 } & 100 元台 & $2.92(1.01)$ & $2.70(0.97)$ & $0.22(0.22)$ & $-0.01-0.44$ \\
\hline
\end{tabular}

また，購買意思については，日本の場合，值段のパターンの主効果がみられ $(F(2,122)=8.319, p<.01)$, ラ イアン法による多重比較の結果, 桁が変わるものと先頭の数字が変わるもの, 桁が変わるものと大台割れでないも のには有意差がみられたが，先頭の数字が変わるものと大台割れでないものには有意差がみられなかった。值段の 桁数の主効果 $(F(1,61)=0.011, n . s$.$) と值段のパターンと桁数の交互作用 (F(2,122)=2.283, n . s$.$) は有意で$ はなかった。95\%信頼区間の結果からも，桁が変わるもののみ，100 円台の場合，1000 円台の場合の両方で元の 值段と值引きした值段の間に有意差が見られ，大台割れでしかも桁が変わる場合に購買意志が高くなることが示唆 された。

一方, 中国の場合, 值段のパターン $(F(2,72)=0.140, n . s$.$) , 桁数の主効果 (F(1,36)=0.170, n . s$.$) , 交互$ 作用 $(F(2,72)=0.014, n . s$.$) すべて有意ではなかった。 95 \%$ 信頼区間の結果から，元の值段と值引きした值段 の差では，桁が変わるものの 10 元台と 100 元台にそれぞれ有意差がみられた。また，先頭が変わるものと大台割 れではないものでは, 10 元台の場合に有意差がみられた。大台割れに関係なく, 安い方を買おうと思う傾向が特 に 10 元台の場合でみられたと言える。

\section{考察}

本研究では消費者の価格判断の過程，特に大台割れ価格の効果について検討を行った。まず，值段に対する印象に ついては，日本の場合，大台割れ価格の効果は見られ，特に桁が変わるものの方は，元の值段と比べて安いと感じ ることが明らかになった。しかし，中国の場合，大台割れに関係なく，割引したものを安いと感じることが示唆さ 
れた。

購買意志については，日本では，桁が変わる場合のみしか有意差は見られず，大台割れ価格の効果は，桁が変 わる場合により強く見られるということが示唆された。また，中国では，大台割れに関係なく，割引されたものの 方を買いたいと思う傾向が特に 10 元台の場合に見られた。日本の場合, 值段が 100 円台であるのか, 1000 円台で あるのかでは特に違いが見られなかったが, 中国の場合, 先頭の数字が変わるものと大台割れではないもので 10 元台のみに有意差が見られた。

このように中国と日本での調査結果は大きく異なり，まず值段を安いと感じるかどうかについては，日本では 大台割れ価格の効果が見られるのに対して, 中国では大台割れに限らず, 值下げした值段を安いと感じている。こ のような結果となった理由について，まず，生活水準の問題があげられる。日本の平均収入は中国より高いため, 買い物する際，中国人の方が日本人より，よりコミットメントが高くなると考えられる。今回調査を行った大連 は，北京や上海ほどではないが，物価は中国では低い方ではなく，日本と比較すると多少低いくらいであった。そ のため，今回設定した值段の商品は，そこまで高いと感じるものではなかったはずであるが，今回の結果からは， 中国人の方がよりシビアに值段を評価していたと考えられる。つまり価格判断に対するコミットメントの高い中 国人の方がより心的モノサシの影響を受けず，值段をそのもので判断をし，コミットメントの低い日本人の方が心 的モノサシの影響を受け，大台割れの価格を安いと感じるという判断をしていたといえる。

また，実際その商品を買いたいと思うかどうかについては，日本でも中国でも，大台割れの中でも，桁が変わ る場合にそれを買いたいと思う傾向がみられた。また，中国では，他の值段パターンでも 10 元台の場合には，安 い方を買いたいと思う傾向がみられた。中国では, 值段に対する評価と同様に, 特に值段が高くなる 100 元台の 方ではよりコミットメントが高くなり，值段が下がったからといって買おうという意思自体が高くなることはな かったのかもしれない。また，100 元台では商品のカテゴリーが服飾品であったため，その影響が出てしまった可 能性も考えられる。

\section{今後の課題}

今回の調査対象は大学生のみであったため, 生活は完全に家族から離れておらず，収入などもばらつきあると考え られる。今後このような傾向が他の年齢層や国籍でも見られるかを検討する必要がある。また，より高額な商品の 場合や商品のカテゴリーなどについても更なる研究が必要である。值段に対するパターンも, 今回は桁の変わる大 台割れの設定が一番価格が安くなるものとなっていたため，そうでないパターンを加えて比較する必要もあると考 えられる。

また，值段に対する評価では，值段が 100 円・10 元台であるのか，1000 円・100 元台であるのかでは特に違 いが見られなかったが，今後，より高額のものでも同じ傾向見られるのかを検討する必要がある。今回は，值段が 安い場合と高い場合で商品のカテゴリーが変わってしまっていた。考察でも述べたように，それが今回の結果に影 響を及ぼした可能性も考えられるため, 今後はカテゴリーを統一するなどして, 購買に対する意欲が統制できるよ うにしたい。

消費者のこの一連の心理をよく理解した, 商店やメーカーでは適切な商品の值段を設定することょり良い経営 を行うことができると考えられる。ただ, 今回の実験手続きでは, 元の值段と值引きした後の值段を同時に提示し ているため, より值引きが意識されやすい設定であったといえる。今後, 元の值段と值引きの值段を被験者間で比 較するなどし，日常の值引き前の値段が書かれていない状況に即した検討が必要であるといえる。 


\section{引用文献}

小嶋外弘, 1986. “価格心理-消費者は何を購入決定の-“モノサシ”にするのか”, ダイヤモンド社.

竹村和久, 1998. “状況依存的意思決定の定性的モデル一心理的モノサシ理論による説明”, 認知科学, 第 5 巻, 第 4 号, pp. 17-34.

竹村和久, 2000. “消費者の価格判断の過程”, 高木修（監修）「消費者行動の社会心理学」, 北大路書房, pp. 52-63. 